\title{
Evidence of the effects of fire on branching and leaf development in
}

\section{cerrado trees}

\author{
João Paulo Souza", Ana Lúcia S. Albino²and Carlos Henrique B. A. Prado²
}

Received: March 30, 2017

Accepted: July 10, 2017

\begin{abstract}
We discuss evidence of effects of an accidental fire on shoot growth and leaf development in six cerrado tree species with distinct leaf phenologies. Buds of all six species were marked before shoot and leaf emergence in the dry season. After fire, leaf and shoot growth were monitored weekly and specific leaf area (SLA) was determined. Shoot order was determined in the growing season. Evergreens and semideciduous woody species had rapid leaf and shoot growth and decreased leaf life span (LLS) after fire compared with published data for evergreens in cerrado areas without fire. On the other hand, Kielmeyera variabilis, a deciduous species, showed intense branching and produced two orders of shoots in one growing season. Fires promote rapid leaf and shoot growth in evergreens owing to reserve accumulations that allow survivorship after disturbances. However, the leaves produced by evergreens after fire had high SLAs and were discarded before the next rainy season (short LLS). This leaf cohort was produced with less carbon per leaf, and the decreased LLS prevented herbivory and water loss during the dry season. Fire is an important factor of cerrado environments, influencing leaf production and shoot architecture in cerrado trees.
\end{abstract}

Keywords: disturbance, leaf life span, shoot growth, specific leaf area, shoot order

\section{Introduction}

Plant architecture is the compromise between environmental constraints and plant body functionality (Sussex \& Kerk 2001; Reinhardt \& Kuhlemeier 2002; Meinzer 2003; Barthélémy \& Caraglio 2007). Crown branching patterns balance the need to expose leaves to light to perform photosynthesis and the need to ensure that light exposure does not damage the photosynthetic apparatus (Souza et al. 2009b). Thus, plant architecture is important for exploiting the horizontal light gradient and refers to the whole plant shape and its spatial arrangement (Poorter et al. 2006).
In the cerrado, there are few studies regarding plant architecture, and most of them concern shoot growth (Rossato \& Franco 2008; Souza et al. 2009a; b; Rossato 2009; Rossato et al. 2009). Only four studies deal with whole crown architecture (Souza et al. 2011; Santos et al. 2012) or modular growth (Damascos et al. 2005; Damascos 2008) of woody cerrado species. In general, cerrado species with perennial foliage adjust shoot growth to the rainy period, while those with deciduous foliage produces leaves and shoots before the first rains (Damascos et al. 2005; Lenza \& Klink 2006; Damascos 2008). According to Lenza \& Klink (2006) and Silvério \& Lenza (2010), evergreens that show intense leaf production only in the rainy period

\footnotetext{
${ }^{1}$ Instituto de Ciências Biológicas e da Saúde, Universidade Federal de Viçosa, Campus Florestal, LMG 818 km 06, 35690-000, Florestal, MG, Brazil ${ }^{2}$ Departamento de Botânica, Universidade Federal de São Carlos, Washington Luis, 13565-905, São Carlos, SP, Brazil
} 
were classified as evergreens with seasonal growth. Woody cerrado species have distinct branching patterns according to their leaf phenology. Evergreen species produce up to three shoot orders in one growing season, while deciduous species produce just one order (Damascos et al. 2005; Damascos 2008). In addition, there are other architectural differences between deciduous and evergreen species in cerrado vegetation. Deciduous species have plagiotropic shoots, where leaves receive a similar amount of light along the shoot (Souza et al. 2009a; b). On the other hand, evergreens have orthotropic shoots, where distal shoot leaves receive greater irradiance than basal shoot leaves. These differences result in a complex crown in evergreens that has more shoots and nodes than in deciduous trees (Souza et al. 2011), which affects light utilization during the day (Santos et al. 2012). However, the crown architecture in cerrado habitats can be modified by environmental characteristics such as periodic fires.

Fire has long shaped vegetation in cerrado regions (Miranda et al. 2002) and occurs in the rainy season primarily from lightning and in the dry period from human actions (Miranda et al. 1993). Woody plants are adapted to this environmental condition and show several morphological traits associated with fire (Simon \& Pennington 2012). The bark tissue of woody species is thick to protect internal tissues from fire damage (Hoffmann et al. 2003; Simon \& Pennington 2012). Fire may stimulate and synchronize flowering and seed production in cerrado species, primarily shrub and herbaceous (Coutinho 1982; Cirne \& Miranda 2008). Fire events can change the balance between sexual and vegetative reproduction to favor the latter (Hoffmann 1999). Owing to reserve structures, such as a xylopodium, cerrado species can resprout more intensely and increase stem radial growth after fire (Hoffmann 2002; Medeiros \& Miranda 2008; Diniz \& Franceschinelli 2014). Even though fire events have direct effects on plant growth, there is no information about fire effects on post-shoot growth and branching in cerrado woody species.

Here we investigated the effect of an accidental fire on shoot growth and branching pattern on six woody cerrado species with distinct leaf phenologies. Fire events can change plant growth, so we expected adjustments in their leaf and shoot growth. In evergreens, fire may change the continuous pattern of leaf production and cause a flush of leaves in a short period to compensate for the lost biomass. In deciduous species, with the whole crown affected by fire, the intense shoot growth with more shoot orders produced in a same growing season is expected. Also, owing to lost biomass on tree crown due to fire event, it is expected an increase in dependence of climate variables, such as precipitation and air temperature, for leaf production and branching, regardless of leaf deciduousness. The study of fire effects on branching patterns in woody cerrado species can improve understanding of fire as a factor shaping cerrado vegetation.

\section{Materials and methods}

\author{
Study area, climate, and fire event
}

The study was carried out in a cerrado sensu stricto area located within an 86-ha natural reserve in the Federal University of São Carlos, São Paulo state, Brazil (215'$22^{\circ} 00^{\prime} \mathrm{S} 47^{\circ} 51^{\prime}-47^{\circ} 52^{\prime} \mathrm{W}$ ). According to the Köppen climatic classification, the region is between $A w$ and $C w a$. The regional climate is tropical with a wet summer between October and March and a dry season between April and September (Damascos et al. 2005). The monthly precipitation and air temperatures during the study period are shown in Figure 1. The soil was classified as a dystrophic Oxisol. The cerrado sensu stricto area studied presents a two-layered system (Ribeiro \& Walter 1998) with herbaceous plants and trees.

There was an intense natural burn on August 2006. The fire affected about $80 \%$ of the Cerrado reserve in Federal University of São Carlos (personal observation). Only K. variabilis plants had their whole aerial part killed by fire event. The others five cerrado species were the crown burned, in general from $50 \%$ to $75 \%$ of the whole aerial part.

\section{Plant species and meteorological conditions in the period of study}

The species chosen for this study were two deciduous trees, Diospyros hispida A. DC. (Ebenaceae) and Kielmeyera variabilis Mart. \& Zucc. (Calophyllaceae); two semideciduous trees, Casearia sylvestris Sw. (Salicaceae) and Eriotheca gracilipes (K. Schum.) A. Robyns (Malvaceae); and two evergreens, Miconia ligustroides (DC.) Naudin (Melastomataceae) and Piptocarpha rotundifolia (Less.) Baker (Asteraceae). The morphological traits for these species are described in Souza et al. (2009a; b).

The pattern of precipitation and air temperature was very marked in both 2006 and 2007 (Fig. 1). Between April and August of 2006 and 2007, low precipitation (except July 2007) and temperatures characterized the dry season. However, between September and March, high precipitation and temperature marked the rainy season (Fig. 1).

\section{Shoot and leaf growth}

Five buds were marked prior to opening on each of five individuals per species ( $\mathrm{n}=5$ per species, 30 total) after an accidental fire on August 2006. The marked buds were from apical resprout in shoots damaged by fire. The cohort of buds was followed from September 2006 to August 2007. Budbreak was recorded when small leaves were seen emerging from the bud, following Damascos et al. (2005). Marked buds and the organs derived from them were observed at 7-d intervals during the wet and dry seasons. 


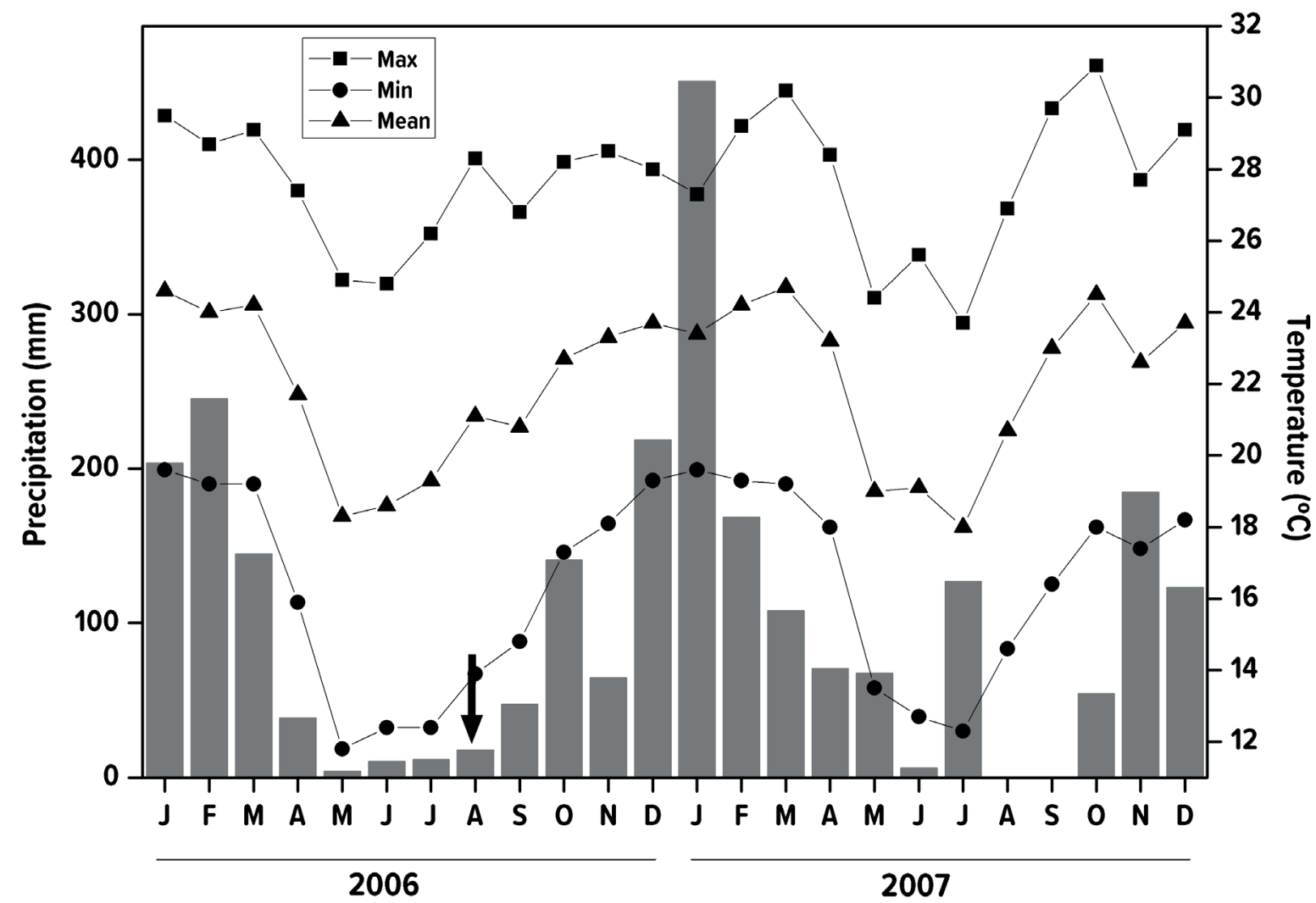

Figure 1. Precipitation and temperature (mean, maximum, and minimum) during 2006 and 2007. The data were recorded at station 83726 of the Brazilian national meteorological service, located $1 \mathrm{~km}$ from the study area. The black arrow indicates the month when the fire occurred.

The number of leaves was monitored on shoots during the whole growing season.

To evaluate leaf and shoot development in six woody cerrado species, the leaf expansion interval (LEI, days to full expansion), leaf expansion rate (LER, mature leaf area divided by LEI, $\mathrm{cm}^{2}$ days ${ }^{-1}$ ), shoot expansion interval (SEI, days to full expansion), shoot expansion rate (SER, mature shoot length by SEI, $\mathrm{cm}$ days $^{-1}$ ) and leaf life span (LLS, days) were determined. The SEI and SER were determined only on A1 shoots of all species. The shoot length and the length and width of each leaf or leaflet were recorded weekly until growth stopped, at which time the SER and LER were calculated. The maximum length and width of each leaf and shoot were measured at each sampling date, using a ruler. The LLS was noted weekly, and leaves were considered finished when about $90 \%$ of the total leaf area was yellowish or when they dropped from the stem.

\section{Branching pattern}

During the growing season (2006-2007), the shoots that emerged from axillary buds on parental shoots were classified as first-order axis (A1) shoots (Barthélémy et al.
1991; Damascos et al. 2005), those produced from axillary buds on A1 shoots were second-order (A2) shoots, and those developed from axillary buds on A2 shoots were third-order (A3) shoots. The final shoot length was determined when shoots stopped growing.

The fate of the apical meristem (flowering, persistence, or abscission) of all shoots (A1, A2, and A3) was determined at the end of the growing season.

\section{Specific leaf area}

In each species, 50 shoots previously marked (currentyear shoots) were utilized for leaf collection. The leaf area was determined for all leaves on these 50 shoots in each of the six species studied. The leaves were digitized with a scanner and the area was determined using the software Image-Pro, version 5.0 (Media Cybernetics, USA). Afterward, leaves were dried in a stove at $60{ }^{\circ} \mathrm{C}$ to constant weight (Pérez-Harguindeguy et al. 2013), and then the mass was measured with an analytical balance (Mettler AE 260 DeltaRange, US). Specific leaf area was obtained by dividing leaf area by leaf dry mass (SLA, $\mathrm{cm}^{2} \mathrm{~g}^{-1}$ ). 


\section{Statistical Analysis}

A one-way analysis of variance (ANOVA) and a posteriori Tukey's test were used to check for differences $(P<0.05)$ among species and species merged into phenological groups in relation to LEI, SEI, LER, SER, LLS, and SLA. Pearson's correlation was used to analyze the relationship between mean monthly number of leaves on A1, A2, and A3 shoots and monthly precipitation and temperature. All statistical analyses were performed with the program $\mathrm{R}$ ( $\mathrm{R}$ Core Team 2014).

\section{Results}

\section{Shoot and leaf growth}

All species had begun A1 shoot extension at the end of September (09/26/2006), with the exception of K. variabilis (deciduous), which only experienced budbreak in early October (10/10/2006).

Miconia ligustroides, an evergreen species, showed the highest LEI (35 days) and SEI (47 days; both $P<0.05$ ), and Eriotheca gracilipes (semideciduous) had the lowest LEI (20 days) and SEI (16 days, Tab. 1), respectively (both $P<$ 0.05). However, E. gracilipes showed the highest LER (3.6 $\mathrm{cm}^{2}$ days $\left.^{-1}\right)$ and SER $\left(0.7 \mathrm{~cm}^{2}\right.$ days ${ }^{-1}$; both $\left.P<0.05\right)$, and $M$. ligustroides and Casearia sylvestris had the lowest LER (0.3 $\mathrm{cm}^{2}$ days $\left.{ }^{-1}\right)$ and $M$. ligustroides the lower SER $\left(0.3 \mathrm{~cm}^{2}\right.$ days ${ }^{-1}$; both $P<0.05 ;$ Tab. 1$)$. The LLS was higher $(P<0.05)$ in $C$. sylvestris (semideciduous, 260 days) and Diospyros hispida (deciduous, 256 days) and lower in Kielmeyera variabilis (deciduous, 183 days). When the data set was merged into phenological groups, deciduous species showed the highest LEI (28 days; $P<0.05$ ), evergreens had the highest SEI (38 days; $P<0.05)$, and semideciduous trees had the highest values of LER $\left(1.9 \mathrm{~cm}^{2}\right.$ days $\left.{ }^{-1}\right)$ and SER $\left(0.6 \mathrm{~cm}^{2}\right.$ days ${ }^{-1}$, Table 1). There was no difference $(P>0.05)$ in LLS among species merged into phenological groups (Tab. 1).

The SLA value was highest in semideciduous $C$. sylvestris $\left(85 \mathrm{~cm}^{2} \mathrm{~g}^{-1}\right)$ and lowest in deciduous $D$. hispida $\left(57 \mathrm{~cm}^{2} \mathrm{~g}^{-1}\right)$. The SLA was lower in deciduous group than in semideciduous and evergreen group when species were merged into phenological groups (Tab. 1).

All six species presented a leaf flush on A1 shoots at the end of dry season, in September 2006, with the exception of $K$. variabilis, which produced a new leaf cohort only in October 2006. The period of leaf flushing on A1 shoots corresponded to the beginning of rains and rising air temperatures (Fig. 1). However, leaf production on A2 shoots began at the end of October 2006 in Casearia sylvestris and K. variabilis and at the end of February 2007 in $M$. ligustroides. Only M. ligustroides produced A3 shoot leaves at the end of April 2007.

In deciduous species, there was a positive correlation (Tab. $2, P<0.05$ ) between monthly precipitation and leaf production on $\mathrm{A} 1$ and $\mathrm{A} 2$ shoots (Tab. 2, Fig. 2), and in $K$. variabilis (deciduous) the leaf production on $\mathrm{A} 1$ shoots was positively correlated $(P<0.05)$ with mean monthly air temperature (Tab. 2, Fig. 2). In semideciduous species E. gracilipes and C. sylvestris, only $\mathrm{A} 1$ leaf production was positively correlated (Table $2, P<0.05$ ) with precipitation and only E. gracilipes with air temperature (Tab. 2, Fig. 2). The leaf production of A1 shoots in evergreens (Piptocarpha rotundifolia and $M$. ligustroides) was positively correlated (Table 2, $P<0.05$ ) with precipitation and temperature, but A2 and A3 leaf production was negatively correlated (Table 2, $P<0.05$ ) with precipitation and temperature in M. ligustroides (Fig. 3).

\section{Branching pattern}

The species $P$. rotundifolia (evergreen), E. gracilipes (semideciduous), and $D$. hispida (deciduous) produced only A1 shoots over the whole growing season (dry and wet periods, Fig. 3). However, K. variabilis (deciduous) and $C$. sylvestris (semideciduous) produced two orders of branching (A1 and A2) in the same season (Fig. 3). Only M. ligustroides produced A3 shoots in the same growing season.

Only deciduous species experienced shoot apex death, and $K$. variabilis had persistent and flowering shoots too. All evergreens and semideciduous species had persistent shoot apices and/or shoot flowering (Fig. 3).

\section{Discussion}

In general, evergreen and semideciduous species produce buds, shoots, and leaves throughout the whole year (Damascos et al. 2005) and are more dependent on shortterm assimilation than deciduous species (Damascos 2008). Organ neo-formation in evergreen and semideciduous cerrado species result in leaf and shoot production along several months in dry and rainy season, expending resources during a longer period. In this way, just a minimum accumulation could be possible owing to continuous nutrient and energy costs, so these species become more dependent of short-term carbon assimilation (Damascos 2008). On the other hand, deciduous species with buds with organ preformation probably spent reserves accumulated in the previous rainy season, since this kind of bud represents an additional cost to the plant, mainly in dry period (Damascos 2008). However, in our study, evergreen species produced leaves and A1 shoots as rapidly as did deciduous species (in approximately 30 days). According to Damascos et al. (2005), evergreen (Miconia albicans (Sw.) Triana) and semideciduous (Leandra lacunosa Cogn.) species in cerrado areas without burning event, typically take 58 and 61 days to expand their leaves, respectively. In addition, fire negatively affected evergreen and semideciduous species' LLS (247 and 241 days, respectively) in our study; the normal LLS of evergreen and semideciduous species in cerrado range 
Table 1. Leaf and shoot growth parameters in six woody cerrado species growing from 2006 to 2007 after a fire. LEI (days) = leaf expansion interval, SEI (days) = shoot expansion interval, LER $\left(\mathrm{cm}^{2}\right.$ days $\left.^{-1}\right)=$ leaf expansion rate, SER $\left(\mathrm{cm} \mathrm{days}^{-1}\right)=\operatorname{shoot}$ expansion rate, LLS (days) = leaf life span, and SLA $\left(\mathrm{cm}^{2} \mathrm{~g}^{-1}\right)=$ specific leaf area. Lowercase letters compare parameters among six species in columns and capital letters compare phenological groups (ANOVA, $P<0.05$ ).

\begin{tabular}{|c|c|c|c|c|c|c|}
\hline Species & LEI & SEI & LER & SER & LLS & SLA \\
\hline \multicolumn{7}{|l|}{ Deciduous } \\
\hline Diospyros hispida & $37 \pm 13 a$ & $26 \pm 7 b c$ & $1.7 \pm 0.6 b$ & $0.4 \pm 0.2 \mathrm{~cd}$ & $256 \pm 6 \mathrm{a}$ & $57 \pm 1.8 c$ \\
\hline Kielmeyera variabilis & $25 \pm 8 b$ & $33 \pm 17 b$ & $1.1 \pm 0.5 c$ & $0.5 \pm 0.3 \mathrm{bcd}$ & $183 \pm 3 c$ & $61 \pm 1.0 c$ \\
\hline Mean \pm SE & $28 \pm 8 A$ & $29 \pm 9 B$ & $1.4 \pm 0.4 \mathrm{~B}$ & $0.4 \pm 0.2 \mathrm{~B}$ & $220 \pm 37 A$ & $59 \pm 1.0 \mathrm{~B}$ \\
\hline \multicolumn{7}{|l|}{ Semideciduous } \\
\hline Casearia sylvestris & $23 \pm 8 c$ & $33 \pm 9 b$ & $0.3 \pm 0.1 d$ & $0.5 \pm 0.1 b c$ & $260 \pm 4 a$ & $85 \pm 1.5 \mathrm{a}$ \\
\hline Eriotheca gracilipes & $20 \pm 10$ de & $16 \pm 10 c$ & $3.6 \pm 2.0 \mathrm{a}$ & $0.7 \pm 0.5 a$ & $220 \pm 4 b$ & $71 \pm 1.7 b$ \\
\hline Mean $\pm \mathbf{S E}$ & $22 \pm 6 C$ & $24 \pm 8 B$ & $1.9 \pm 1.0 \mathrm{~A}$ & $0.6 \pm 0.3 \mathrm{~A}$ & $241 \pm 19 A$ & $78 \pm 1.2 \mathrm{~A}$ \\
\hline \multicolumn{7}{|l|}{ Evergreens } \\
\hline Miconia ligustroides & $35 \pm 13 a$ & $47 \pm 24 a$ & $0.3 \pm 0.1 \mathrm{~d}$ & $0.3 \pm 0.1 \mathrm{~d}$ & $248 \pm 8 \mathrm{ab}$ & $78 \pm 2.6 \mathrm{ab}$ \\
\hline Piptocarpha rotundifolia & $19 \pm 8$ e & $29 \pm 10 b$ & $1.3 \pm 0.6 \mathrm{bc}$ & $0.6 \pm 0.4 \mathrm{ab}$ & $245 \pm 8 \mathrm{ab}$ & $77 \pm 2.0 \mathrm{ab}$ \\
\hline Mean \pm SE & $26 \pm 9 B$ & $38 \pm 13 A$ & $0.8 \pm 0.3 C$ & $0.5 \pm 0.2 \mathrm{~B}$ & $247 \pm 2 A$ & $78 \pm 1.7 \mathrm{~A}$ \\
\hline
\end{tabular}

Table 2. Pearson's correlation coefficient among the leaf production on $A 1, A 2$ and $A 3$ shoots and precipitation and air temperature in six woody cerrado species. $\mathrm{T}=$ air temperature; $\mathrm{P}=$ precipitation. Bold values indicate $P<0.05$.

\begin{tabular}{|c|c|c|c|c|c|c|}
\hline Species & \multicolumn{5}{|c|}{$\mathrm{R}^{2}$ values } & $\mathrm{A} 3 \times \mathrm{T}$ \\
\hline & $\mathrm{A} 1 \times \mathrm{T}$ & $\mathrm{A} 1 \times \mathrm{P}$ & $\mathrm{A} 2 \times \mathrm{T}$ & $\mathrm{A} 2 \times \mathrm{P}$ & $\mathbf{- 0 . 6}$ & $-\mathbf{0 . 6}$ \\
\hline M. ligustroides & $\mathbf{0 . 6}$ & $\mathbf{0 . 7}$ & $\mathbf{- 0 . 6}$ & $\mathbf{- 0 . 5}$ & - \\
\hline P. rotundifolia & $\mathbf{0 . 6}$ & $\mathbf{0 . 7}$ & - & - & - \\
\hline C. sylvestris & $\mathbf{0 . 7}$ & $\mathbf{0 . 7}$ & -0.2 & 0.2 & - \\
\hline E. gracilipes & $\mathbf{0 . 2}$ & $\mathbf{0 . 7}$ & - & - & - \\
\hline K. variabilis & $\mathbf{0 . 7}$ & $\mathbf{0 . 8}$ & 0.4 & $\mathbf{0 . 6}$ & - \\
\hline D. hispida & $\mathbf{0 . 3}$ & $\mathbf{0 . 7}$ & - & - & - \\
\hline
\end{tabular}

from approximately 364 to 780 days for evergreens (Lenza 2005; Damascos et al. 2005; Franco et al. 2005) and from 247 to 371 for semideciduous (Damascos et al. 2005). Even with the lack of LLS data from cerrado species published in the literature, the LLS from our species seem to have been adversely affected by fire. Also, fire increased the speed of shoot expansion of evergreens. Rossato \& Franco (2008), studying five evergreens from cerrado found shoot mean growth ranging from 0.23 to $1.38 \mathrm{~cm}$ per month. In our study, $M$. ligustroides and $P$. rotundifolia showed mean shoot growth range from 9 to $18 \mathrm{~cm}$ for month. Therefore, the fire could increase the speed of leaf and shoot expansion in evergreens and semideciduous woody cerrado species but decreased LLS. Another morphological adjustment of evergreens and semideciduous trees was a decreased SLA (Tab. 1). In a study with 125 woody species, Cianciaruso et al. (2013) found no evidence of differences in SLA among distinct phenological groups in cerrado vegetation, but in our study, leaves of evergreens and semideciduous species had more area than mass per leaf. Therefore, less carbon was allocated per leaf and with a thinner structure; there was a decrease in LLS. This low LLS associated with high SLA could result in similar values of net photosynthesis between evergreens and deciduous species, as found by Souza et al. (2009b), who studied the same species in the cerrado area. The low LLS in evergreens and semideciduous species could be linked with high SLA values and together higher air temperatures and lower soil moisture in the burned area induces plants to drop their leaves to reduce water loss in the dry season. Therefore, decreased LLS allowed evergreen leaves to translocate resources from old to new leaves and not lose resources. In cerrado, woody species showed nutrient translocation, primarily $\mathrm{K}, \mathrm{Mg}, \mathrm{P}$ and $\mathrm{N}$, from old to new leaves (Medeiros \& Haridasan 1985; Leitão \& Silva 2004), hence, the young leaves could maintain the level of nutrients in the plant (Leitão \& Silva 2004).

According to Simon \& Pennington (2012), fire-resistant traits such as thick bark and a xylopodium have evolved together with the rise to dominance of flammable $C_{4}$ grasses, which are common in the cerrado. Cerrado species are adapted to frequent fires so the quick shoot growth in all six species could be the result of reserve accumulations that allow plants to survive fire disturbance (Braz et al. 2000). This is primarily when species are top killed by fire, as Kielmeyera variabilis was in our study, that they exhibit intense resprouting. Kielmeyera variabilis showed high leaf and shoot expansion together with the lowest LLS. In addition, $K$. variabilis produced two orders of shoots in the same growing season. Deciduous species produce only one order of shoots per growing season (Damascos et al. 2005; Damascos 2008), originating from buds with preformed organs. Owing to the death of the whole crown in 


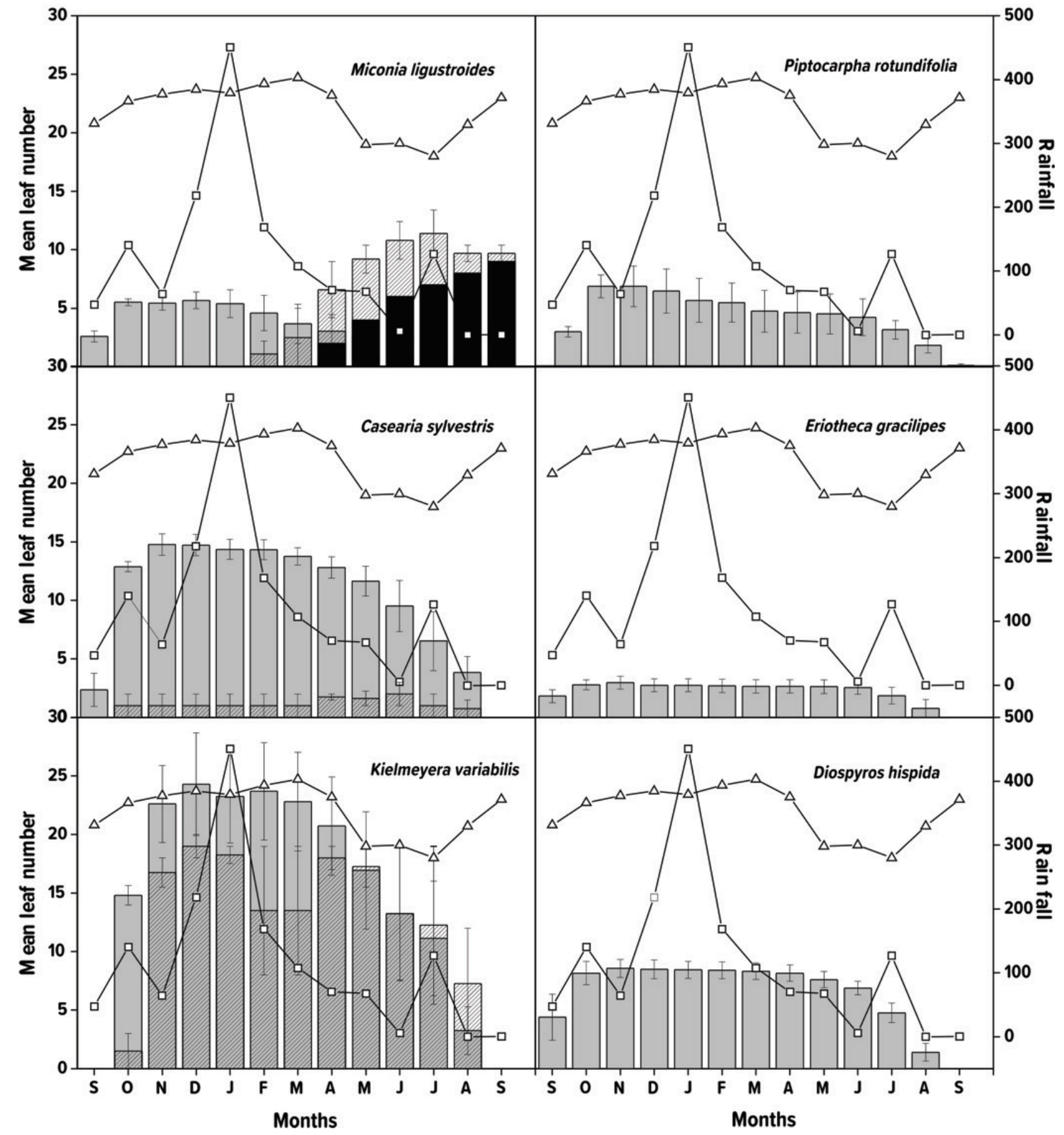

Figure 2. Leaf number produced during dry and wet seasons in 2006 and 2007 on shoots of A1 (gray columns), A2 (inclined lines), and A3 (black columns) in the six cerrado species studied. The line with triangles indicates the mean air temperature and the line with squares indicates the mean monthly precipitation. 


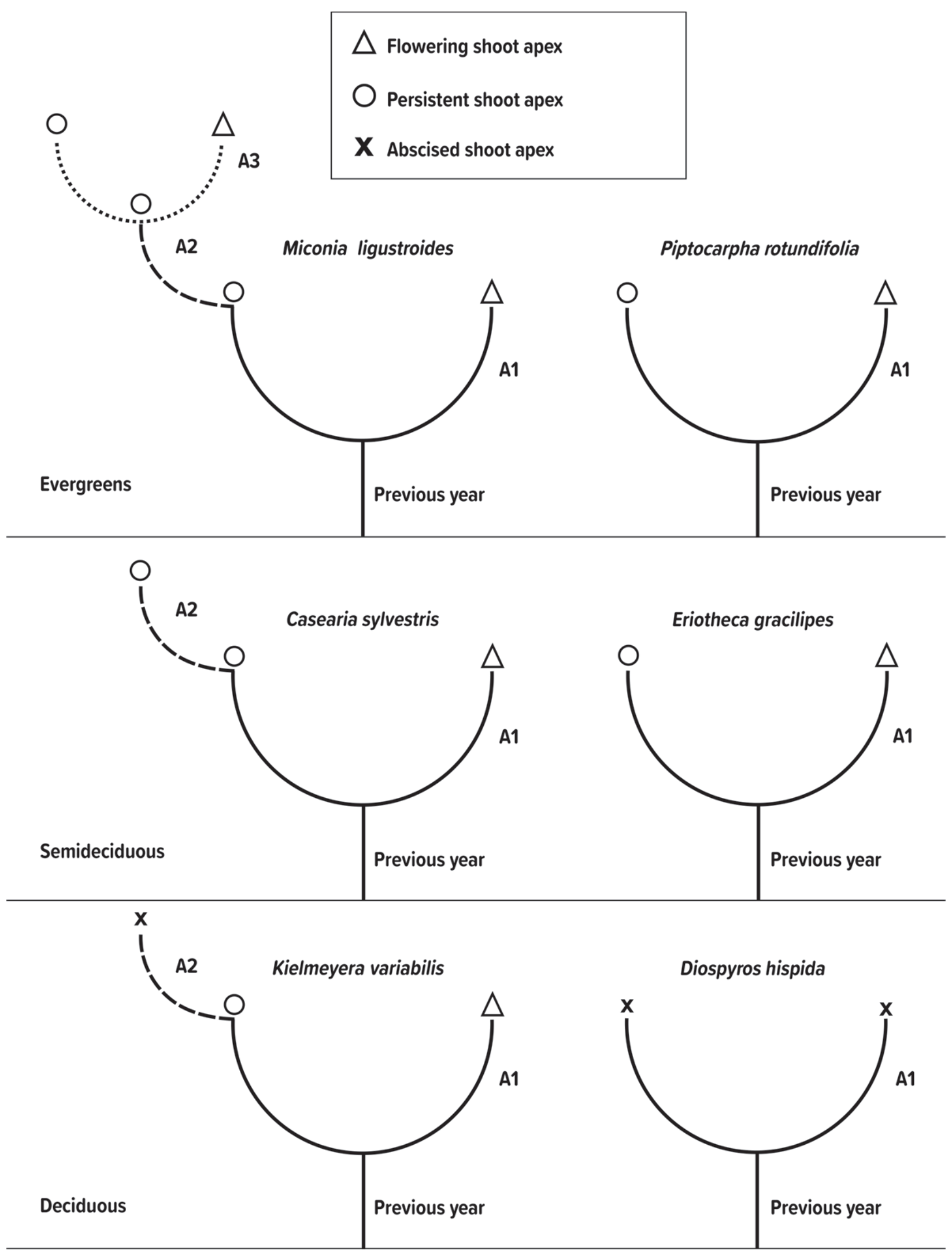

Figure 3. Branching diagrammatic representation of the six woody cerrado species studied, during the dry and wet seasons in 2006. A1, first order axis (continuous line) emerged at the beginning of the wet season; A2, second-order axis (dashed lines) emerged from axillary buds of A1 shoots; A3, third-order axis (dotted lines) emerged from axillary buds of A2 shoots. Previous-year shoots are shown as thick lines at the base. Based on Damascos et al. (2005). 
K. variabilis, the subsequent aboveground growth involved a massive, rapid flush from root buds to replace the entire aerial structure lost in the fire. Also, the fast shoot growth showed by the cerrado species studied may be the result of ash deposition after fire in the soil surface (Silva \& Batalha 2008; Pivello et al. 2010). Ashes release soluble compounds fertilizing the soil and providing higher nutrient content, mainly $\mathrm{N}, \mathrm{K}$ and $\mathrm{Mg}$, for quick use by plant species.

Another phenological adjustment due to the fire was the positive relationship of leaf production on $\mathrm{A} 1$ shoots with precipitation and temperature in evergreen species. Miconia albicans, an evergreen species, did not present a correlation between leaf production on $\mathrm{A} 1$ shoots and precipitation and temperature (Damascos et al. 2005). However, following fire, evergreens ( $M$. ligustroides and $P$. rotundifolia) adjust and produce a flush of leaves to replace the photosynthetic area in a short period.

Fires promoted leaf and shoot growth in the six cerrado trees. Cerrado trees are adapted to fire events and even with high damage on the crown, they showed intense and accelerated shoot and leaf development after fire, especially in the evergreens and semideciduous species. On the other hand, if the fire damage involves the whole crown, the branching pattern can be altered and more shoot orders can be produced in the same growing season, even in deciduous species. It is important to study the relationship between fire and shoot and leaf development to understanding how fire modulates leaf production and whole-plant architecture in cerrado vegetation. Further studies on the relationship between fire and aerial growth of trees will help understanding how fire shape modular growth of cerrado trees.

\section{Acknowledgements}

JPS acknowledge the scholarships awarded by Conselho Nacional de Desenvolvimento Científico e Tecnológico, CNPq - Brazil. The authors are also grateful to Professor Hélder Canto Resende for assisting in the making of the figures.

\section{References}

Barthélémy D, Caraglio Y. 2007. Plant architecture: a dynamic, multilevel and comprehensive approach to plant form, structure and ontogeny. Annals of Botany 99: 375-407.

Barthélémy D, Edelin C, Hallé F. 1991. Canopy architecture. In: Raghavendra AS. (ed.) Physiology of trees. New York, John Wiley \& Sons. p. 1-5.

Braz VS, Kanegae MF, Franco AC. 2000. Estabelecimento e desenvolvimento de Dalbergia miscolobium Benth. Em duas fitofisionomias típicas dos cerrados do Brasil central. Acta Botanica Brasilica 14: 27-35.

Cianciaruso MV, Silva IA, Manica LT, Souza JP. 2013. Leaf habitat does not predict leaf functional traits in cerrado woody species. Basic and Applied Ecology 14: 404-412.

Cirne P, Miranda HS. 2008. Effects of prescribed fires on the survival and release of seeds of Kielmeyera coriacea (Spr.) Mart. (Clusiaceae) in savannas of central Brazil. Brazilian Journal of Plant Physiology 20: $197-204$
Coutinho LL. 1982. Ecological effects of fire in Brazilian Cerrado. In: Huntley BJ, Walker BH. (eds.) Ecology of tropical savannas. Berlin, Springer-Verlag. p. 273-291.

Damascos MA. 2008. Conteúdo das gemas, momento da brotação e padrão de produção de folhas em espécies lenhosas do cerrado. Barueri, Manole.

Damascos MA, Prado CHBA, Ronquim CC. 2005. Bud composition, branching patterns and leaf phenology in cerrado woody species. Annals of Botany 96: 1075-1084.

Diniz VSS, Franceschinelli EV. 2014. Estrutura populacional e brotamento de três espécies nativas do cerrao em diferentes regimes de queimada. Revista de Biologia Neotropical 11: 107-115.

Franco AC, Bustamante M, Caldas LS, et al. 2005. Leaf functional traits of neotropical savanna trees in relation to seasonal water deficit. Trees 19: 326-335.

Hoffmann WA. 1999. Fire and population dynamics of woody plants in a neotropical savanna: matrix model projections. Ecology 80: 1354-1369.

Hoffmann WA. 2002. Direct and indirect effects of fire on radial growth of cerrado savanna trees. Journal of Tropical Ecology 18: 137-142.

Hoffmann WA, Orthen B, Nascimento PKW. 2003. Comparative fire ecology of tropical savanna and forest trees. Functional Ecology 17: 720-726.

Leitão AC, Silva AO. 2004. Variação sazonal de macronutrientes em uma espécie arbórea de cerrado, na reserva biológica e estação experimental de Mogi-Guaçu, estado de São Paulo, Brasil. Rodriguésia 55: 127-136.

Lenza E, Klink CA. 2006. Comportamento fenológico de espécies lenhosas em um cerrado sentido restrito de Brasília, DF. Revista Brasileira de Botânica 29: 627-638.

Lenza E. 2005. Fenologia, demografia foliar e características foliares de espécies lenhosas em um cerrado sentido restrito no distrito federal e suas relações com as condições climáticas. $\mathrm{PhD}$ Thesis, Universidade de Brasília, Brasília.

Medeiros MB, Miranda HS. 2008. Post-fire resprouting and mortality in cerrado woody plant species over a three-year period. Edinburgh Journal of Botany 65: 53-68.

Medeiros RA, Haridasan M. 1985. Seasonal variations in the foliar concentrations of nutrients in some aluminium accumulating and non-accumulating species of the cerrado region of central Brazil. Plant and Soil 88: 433-436.

Meinzer FC. 2003. Functional convergence in plant responses to the environment. Oecologia 134:1-11.

Miranda AC, Miranda HS, Dias IF, Dias BF. 1993. Soil and air temperatures during prescribed cerrado fires in Central Brazil. Journal of Tropical Ecology 9: 313-320.

Miranda HS, Bustamante MMC, Miranda AC. 2002. In: Oliveira OS, Marquis RJ. (eds.) The cerrados of Brazil: ecology and natural history of a neotropical savanna. New York, Columbia University Press. p. 51-68.

Pérez-Harguindeguy N, Diaz S, Garnier E, et al. 2013. New handbook for standardised measurement of plant functional traits worldwide. Australian Journal of Botany 61: 167-234.

Pivello VR, Oliveras I, Miranda HS, Haridasan M, Sato MN, Meirelles ST. 2010. Effect of fires on soil nutrient availability in an open savanna in central Brazil. Plant and Soil 337: 111-123.

Poorter L, Bongers L, Bongers F. 2006. Architecture of 54 moist-forest tree species: traits, trade-offs, and functional groups. Ecology 87 : 1289-1301.

R Core Team. 2014. A language and environment for statistical computing. Vienna, R Foundation for Statistical Computing.

Reinhardt D, Kuhlemeier C. 2002. Plant architecture. EMBO Reports 3: 846-851.

Ribeiro JF, Walter BMT. 1998. Fitofisionomias do bioma cerrado. In: Sano SM, Almeida SP. (eds.) Cerrado: ambiente e flora. Planaltina, Embrapa. p. 89-166.

Rossato DR. 2009. Branch elongation and diameter growth were temporarily dissociated in "cerrado" tree species. Hoehnea 36: 437-444.

Rossato DR, Franco AC. 2008. Expansão e mortalidade de ramos em espécies arbóreas de cerrado sensu stricto. Brasileira de Botânica 31: 715-719.

Rossato DR, Hoffmann WA, Franco AC. 2009. Differences in growth patterns between co-occurring forest and savanna trees affect the forest-savanna boundary. Functional Ecology 23: 689-698. 


\section{Evidence of the effects of fire on branching and leaf development in cerrado trees}

Santos KM, Consolaro HN, Moreno MIC, Prado CHBA, Souza JP. 2012. Relationships between crown architecture and available irradiance in two cerrado species with different leaf phenologies. Brazilian Journal of Botany 35: 339-345.

Silva DM, Batalha MA. 2008. Soil-vegetation relationships in cerrados under differente fire frequencies. Plant and Soil 311: 87-96.

Silvério DV, Lenza E. 2010. Fenologia de espécies lenhosas em um cerrado típico no parque municipal de Bacaba, Nova Xavantina, Mato Grosso, Brasil. Biota Neotropica 10: 205-216.

Simon MF, Pennington T. 2012. Evidence for adaptation to fire regimes in the tropical savannas of the Brazilian cerrado. International Journal of Plant Sciences 173: 711-723.
Souza JP, Prado CHBA, Albino ALS, Damascos MA. 2009a. Shoot-foliage relationships in deciduous, semideciduous, and evergreen cerrado tree species. Brazilian Journal of Plant Physiology 21: 75-86.

Souza JP, Prado CHBA, Albino ALS, Damascos MA, Souza GM. 2011. Network analysis of tree crowns distinguishes functional groups of cerrado species. Plant Ecology 212: 11-19.

Souza JP, Prado CHBA, Damascos MA, Albino ALS. 2009b. Influence of shoot inclination on irradiance and morphophysiological leaf traits along shoots in cerrado trees with distinct leaf deciduousness. Brazilian Journal of Plant Physiology 21: 281-289.

Sussex IM, Kerk NM. 2001. The evolution of plant architecture. Current Opinion in Plant Biology 4: 33-37. 